\title{
Perencanaan Angkutan Pemadu Moda Bandara H.A.S. Hanandjoedin
}

\author{
(Operational Planning of Integrated Mode Transport at H.A.S. Hanandjoedin Airport)
}

\author{
SHERLY DEVIANTY
}

\begin{abstract}
ABSTRAK
Meningkatnya pergerakan orang maupun barang di Bandara H.A.S. Hanandjoedin memerlukan perhatian dari berbagai pihak dalam rangka peningkatan kualitas sarana dan prasarana pendukung transportasi dalam memperlancar aktivitas ekonomi dan sosial. Kondisi Bandara H.A.S. Hanandjoedin di Tanjung Pandan saat ini tidak terlayani transportasi umum, hal ini menyulitkan penumpang untuk menuju/dari Bandara. Oleh karena itu, perlu adanya peningkatan layanan transportasi salah satunya adalah dengan menyediakan angkutan pemadu moda sebagai akses menuju Bandara dan/atau sebaliknya. Penelitian ini dilakukan untuk menganalisis potensi demand dan merencanakan sistem operasional angkutan pemadu moda di Bandara H.A.S. Hanandjoedin. Metode pengumpulan data dilakukan dengan teknik stated preference (SP) dengan menggunakan kuesioner yang didistribusikan di Bandara H.A.S. Hanandjoedin. Teknik analisis menggunakan ordered probit model dengan software Limdep versi 7.0 untuk mengetahui tingkat kemauan responden menggunakan layanan angkutan pemadu moda sebagai dasar untuk merencanakan sistem operasional angkutan pemadu moda serta sarana dan prasarananya. Berdasarkan hasil analisis yang telah dilakukan diperoleh potensi demand angkutan pemadu moda adalah sebanyak 575 orang/hari. Jumlah tersebut merupakan jumlah demand dengan rute Tj.Tinggi - Bandara dan sebaliknya. Waktu pelayanan didesain selama $12 \mathrm{jam} /$ hari dengan kendaraan pertama beroperasi pada pukul 05.00 dan pelayanan terakhir berangkat dari bandara mengikuti kedatangan pesawat yang terakhir. Angkutan pemadu moda yang akan digunakan adalah kendaraan bus sedang dengan kapasitas 24 orang, dengan tarif Rp. 10.000, waktu perjalanan 45 menit, headway 21 menit dan jumlah kendaraan yang dibutuhkan adalah sebanyak 6 unit.
\end{abstract}

Kata kunci: angkutan pemadu moda, potensi demand, sistem operasional

\section{ABSTRACT}

The increasing of air plane passenger and goods in H.A.S. Hanandjoedin airport need attention from many parties to improve the quality of supported transportation facilities to carry on economics and social activities. H.A.S. Hanandjoedin airport in Tanjung Pandan is currently not served by public transportation. So the goverment should be able to fullfill the need of efective and efisien public transportation. The porposes of this research are to analyze the potential demand and planning the characteristic operational system of integrated mode transport in H.A.S. Hanandjoedin Airport. The data collection of the research use a stated preference survey $(S P)$ with questioners that are distributed in H.A.S. Hanandoedin Airport. The research result shows that the potential demand of integrated mode transport are 575 people/day. The service time is designed for 12 hours/day with the first vehicle operating at 05.00 and the last service depart from the airport following the arrival of the last arrived. The integrated mode transport that will be used are vehicle with a capacity of 24 people, a tariff of Rp.10.000, travel time are 45 minutes, headway 21 minutes and number of vehicles needed are 6 units.

Keywords: integrated mode transport, potential demand, operational system. 


\section{PENDAHULUAN}

Bandara H.A.S. Hanandjoedin merupakan bandara yang terletak di Tanjung Pandan, Kabupaten Belitung, Kepulauan Bangka Belitung. Jumlah penumpang pesawat di Bandara H.A.S. Hanandjoedin terus meningkat setiap tahunnya. Pada tahun 2015 jumlah penumpang pesawat udara sebanyak 354.514 meningkat dari tahun sebelumnya sebanyak 305.524. Hal tersebut akan berpengaruh terhadap pergerakan yang terjadi di Bandara. Perubahan status Bandara H.A.S. Hanandjoedin menjadi Bandara Internasional tentunya harus diikuti dengan perbaikan pelayanan, baik berupa pembangunan infrastruktur, terminal serta fasilitas pendukung di Bandara H.A.S. Hanandjoedin.

Mengingat belum tersedianya sarana transportasi publik yang khusus melayani bandara, maka perlu direncanakan jaringan trayek/rute angkutan pemadu moda serta sistem pengoperasionalannya di Bandara H.A.S. Hanandjoedin. Angkutan pemadu moda adalah angkutan khusus dalam trayek yang dilaksanakan untuk melayani penumpang dari dan/atau ke terminal, stasiun kereta api, pelabuhan dan bandar udara kecuali dari terminal ke terminal.

Dalam pengembangan angkutan pemadu moda, ada berbagai hal yang perlu diperhatikan seperti penentuan trayek/rute dan jumlah armada dari angkutan khusus tersebut. Hal inilah yang melatarbelakangi penelitian ini dalam menyediakan sarana transportasi umum di Bandara, melalui perencanaan angkutan pemadu moda dari dan ke Bandara H.A.S. Hanandjoedin. Tujuan penelitian ini adalah untuk menganalisis potensi demand dalam perencanaan angkutan pemadu moda menuju Bandara H.A.S. Hanandjoedin dan merencanakan sistem operasional angkutan yang dapat diterapkan.

Manfaat yang diharapkan dari penelitian ini adalah sebagai masukan dan bahan pertimbangan bagi Pemerintah Kabupaten Belitung, operator penyedia layanan jasa maupun pihak lain yang terkait dalam menyediakan layanan transportasi umum khususnya angkutan pemadu moda Bandara H.A.S. Hanandjoedin.

Merujuk pada Undang-Undang Republik Indonesia Nomor 22 Tahun 2009 pada bagian kedua pasal 139 ayat 3 Tentang Jaminan Ketersediaan Sarana Transportasi menyebut bahwa "Pemerintah Kabupaten/Kota wajib menjamin tersedianya angkutan umum untuk jasa angkutan orang dan/atau barang dalam wilayah kabupaten/kota". Pemerintah sebagai penyelenggara angkutan wajib memberikan jaminan kepada pengguna jasa angkutan umum untuk mendapatkan pelayanan yang baik dan layak bagi masyarakat. Ukuran pelayanan yang baik adalah pelayanan yang aman, cepat, murah dan nyaman.

Indikator kinerja pelayanan angkutan umum yang harus dipertimbangkan menurut Supriyanto dan Widiyanti (2010) dengan melakukan penelitian angkutan umum di Kota Surabaya adalah sebagai berikut:

1. Frekuensi

2. Headway

3. Faktor muat

Faktor yang mempengaruhi dalam pemilihan moda transportasi bagi calon pengguna menurut Joint Research Centre (2008) dan Prasetya dan Muthohar (2012) di antaranya adalah:

1. Ketersediaan

2. Waktu akses

3. Biaya akses

4. Frekuensi

5. Kenyamanan

6. Kehandalan

Menurut Pearmain dan Kroes (1990), teknik Stated Preference adalah teknik untuk mendapatkan pernyataan yang merupakan respon dari masyarakat atas berbagai alternatif pilihan yang ditawarkan. Penggunaan teknik stated preference dianggap sebagai suatu metode pengumpulan data yang relatif efektif dan efisien. Langkah yang dilakukan untuk mengidentifikasi bagaimana responden merespon jika suatu kondisi imaginer yang diberikan benar-benar ada dalam realita adalah dengan menanyakan langsung pada responden tersebut. Kemudian peneliti dapat melakukan kontrol terhadap semua faktor yang dibuat dalam alternatif pilihan yang ditawarkan. Pendapat responden tersebut bisa dinyatakan dalam bentuk rangking, rating maupun pilihan. Dalam penelitian ini digunakan model pilihan diskrit (Discrete Choice Models), yang merupakan suatu model probabilitas di mana nilai dari masing-masing pilihan responden berkaitan dengan pilihan-pilihan lainnya dalam alternatif yang ditawarkan. 
Penentuan ukuran sampel dalam penelitian ini menggunakan formula dari Slovin, tertera pada Persamaan (1).

$$
\begin{aligned}
& n=\frac{N}{1+N e^{2}} \\
& \mathrm{n} \quad=\text { Ukuran sampel } \\
& \mathrm{N} \quad=\text { Ukuran populasi } \\
& \text { e }=\text { persen kelonggaran ketidaktelitian }
\end{aligned}
$$

Direktorat Jenderal Perhubungan Darat telah menetapkan standar kualitas pelayanan angkutan kota, yang dapat digunakan dalam perencanaan sistem operasional pada pelayanan angkutan pemadu moda. Standar pelayanan tersebut meliputi: waktu siklus, headway, dan perhitungan kebutuhan armada (Departemen, 1996).

a. Perhitungan waktu siklus

$$
\begin{aligned}
& \mathrm{CT}_{\mathrm{ABA}}=\left(\mathrm{T}_{\mathrm{AB}}+\mathrm{T}_{\mathrm{BA}}\right)+\left(\sigma_{\mathrm{AB}}{ }^{2}+\sigma_{\mathrm{BA}}{ }^{2}\right)+ \\
& \left(\mathrm{T}_{\mathrm{TA}+} \mathrm{T}_{\mathrm{TB}}\right)
\end{aligned}
$$

b. Perhitungan waktu antara (headway)

c. Perhitungan kebutuhan armada

$$
\mathrm{Jk}=\frac{\mathrm{CT}}{\operatorname{HxfA}}
$$

dengan,

$\mathrm{Jk}=$ Jumlah kendaraan yang dibutuhkan

$\mathrm{CT}=$ Waktu sirkulasi (menit)

$\mathrm{H}$ = Headway/waktu antara kendaraan angkutan kota (menit)

$\mathrm{FA}=$ Faktor ketersediaan kendaraan angkutan kota (\%)

\section{METODE PENELITIAN}

\section{Pengumpulan Data}

Data sekunder dalam penelitian ini diperoleh dari instansi-instansi terkait dan memiliki kewenangan tentang data tersebut seperti Dinas Perhubungan Kabupaten Belitung dan UPT Bandara H.A.S. Hanandjoedin. Data sekunder yang dibutuhkan dalam penelitian ini antara lain data jaringan jalan di pulau Belitung, jumlah penumpang dan jumlah pesawat (kedatangan dan keberangkatan) di Bandara H.A.S. Hanandjoedin serta jadwal kedatangan dan keberangkatan pesawat. Hal ini diperlukan dalam perencanaan operasional angkutan pemadu moda di Bandara H.A.S. Hanandjoedin dan juga penentuan jadwal angkutan pemadu moda yang akan beroperasi. Sedangkan data primer diperoleh melalui teknik Stated Preference (SP), di mana teknik ini dilakukan dengan survei kuesioner kepada 100 responden yang merupakan penumpang angkutan udara di Bandara H.A.S. Hanandjoedin. Jumlah responden diperoleh dari hasil perhitungan sampel menggunakan rumus Solvin dengan dasar bahwa jumlah populasi sebesar 1207 penumpang/hari. Perhitungan dengan menggunakan rumus Solvin, didapat jumlah sampel yang dibutuhkan adalah 93 sampel. Untuk mendapatkan hasil yang lebih maksimal sampel penelitian dibulatkan menjadi 100 responden.

\section{Penyusunan Atribut}

Langkah awal dalam membuat formulir survei adalah penetapan variabel atribut pelayanan serta nilai dari masing-masing atribut pelayanan yang akan digunakan dalam mendesain kuesioner. Berdasarkan pengamatan di lapangan dan studi terdahulu maka digunakan lima atribut (tarif, waktu perjalanan, jadwal keberangkatan, tipe perjalanan, dan fasilitas pelayanan) yang berpengaruh terhadap pemilihan moda dan kesediaan calon penumpang untuk menggunakan angkutan pemadu moda. Masing-masing atribut terdiri dari dua level di mana kelima atribut tersebut merupakan variable independent. Pada penelitian ini responden menyatakan pilihannya dengan menggunakan teknik rating, yang dibagi menjadi lima skala ordinal dan merupakan variable dependent. Atribut dapat dilihat pada Tabel 1. 
TABEL 1. Atribut angkutan pemadu moda (bus) bandara

\begin{tabular}{|c|c|c|c|c|}
\hline Variabel & Atribut & Keterangan & & Level \\
\hline \multirow{10}{*}{$\begin{array}{c}\text { Variable } \\
\text { Independent }\end{array}$} & \multirow{2}{*}{ Tarif (travel cost) } & Rp. 15.000 & Mahal & 0 \\
\hline & & Rp. 10.000 & Murah & 1 \\
\hline & \multirow{2}{*}{$\begin{array}{l}\text { Waktu perjalanan } \\
\text { (travel time) }\end{array}$} & $\begin{array}{l}60 \text { menit (berhenti di tempat } \\
\text { pemberhentian) }\end{array}$ & Lama & 0 \\
\hline & & 45 menit (langsung ke bandara) & Cepat & 1 \\
\hline & \multirow{2}{*}{$\begin{array}{c}\text { Jadwal } \\
\text { keberangkatan }\end{array}$} & Tidak terkoordinasi & $\begin{array}{c}\text { Tidak } \\
\text { terkoordinasi }\end{array}$ & 0 \\
\hline & & Terkoordinasi & Terkoordinasi & 1 \\
\hline & \multirow{2}{*}{ Tipe perjalanan } & Tidak langsung & Tidak langsung & 0 \\
\hline & & langsung & Langsung & 1 \\
\hline & & $\begin{array}{l}\text { Bersih, AC, bagasi, jaminan } \\
\text { tempat duduk }\end{array}$ & Baik & 0 \\
\hline & fasilitas & $\begin{array}{c}\text { Sangat bersih, AC, Wifi, bagasi, } \\
\text { jaminan tempat duduk, } \\
\text { tanggungan asuransi }\end{array}$ & Sangat baik & 1 \\
\hline \multirow{5}{*}{$\begin{array}{l}\text { Dependent } \\
\text { Variable }\end{array}$} & \multirow{5}{*}{$\begin{array}{c}\text { Respon } \\
\text { penumpang }\end{array}$} & \multicolumn{2}{|l|}{ Pasti tidak naik } & 0 \\
\hline & & \multicolumn{2}{|l|}{ Mungkin tidak naik } & 1 \\
\hline & & \multicolumn{2}{|l|}{ Ragu-ragu } & 2 \\
\hline & & \multicolumn{2}{|l|}{ Mungkin naik } & 3 \\
\hline & & \multicolumn{2}{|l|}{ Pasti naik } & 4 \\
\hline
\end{tabular}

\section{Pembuatan Skenario/Alternatif Pilihan}

Berdasarkan hasil studi literatur terkait atau penelitian sejenis yang dilakukan serta berdasarkan fenomena yang terjadi di lapangan kemudian dilakukan desain formulir survei yang akan menjadi bahan untuk wawancara. Bagian terpenting pada tahapan ini adalah penetapan variabel dan penyusunan skenario atau alternatif pilihan kepada responden. Pada penelitian ini, formulir survei terdiri dari beberapa bagian yaitu bagian pertama berisi data karakteristik responden, bagian kedua berisi informasi perjalanan dan bagian ketiga adalah preferensi calon pengguna terhadap layanan angkutan pemadu moda bandara. Pada bagian ketiga, terdiri dari dua sub bagian yang di mana yang pertama yaitu pemilihan jenis kendaraan dan kapasitas muatan untuk kendaraan rencana dan pada bagian kedua terdiri dari beberapa alternatif yang diberikan terkait pelayanan yang diinginkan.

Alternatif yang diberikan dibuat dengan mengkombinasikan seluruh atribut beserta levelnya maka akan diperoleh sebanyak 32 skenario/alternatif kombinasi $(2 \times 2 \times 2 \times 2 \times 2$ atau $2^{5}$ ). Untuk memudahkan responden dalam memilih, alternatif yang ada kembali disaring yang jawabannya sudah pasti, artinya alternatif tersebut tidak perlu dimasukkan lagi melalui proses pembauran (confounding) dengan menggunakan desain oleh Cochran and Cox (1957) dan Sugiyanto dan Malkhamah (2009). Desain kuesioner terdiri dari delapan alternatif pilihan seperti yang terdapat pada Tabel 2 .

TABEL 2. Kombinasi perlakuan faktorial $2^{5}$ dalam 8 unit

\begin{tabular}{ccccccc}
\hline \multirow{2}{*}{ Pilihan } & \multirow{2}{*}{$\begin{array}{c}\text { Kombinasi } \\
\text { perlakuan }\end{array}$} & Tarif & Waktu & $\begin{array}{c}\text { Jadwal } \\
\text { keberangkatan }\end{array}$ & $\begin{array}{c}\text { Tipe } \\
\text { perjalanan }\end{array}$ & fasilitas \\
\hline 1 & $(-)$ & - & - & - & - & - \\
2 & $\mathrm{AB}$ & + & + & - & - & - \\
3 & $\mathrm{CD}$ & - & - & + & + & - \\
4 & $\mathrm{ACE}$ & + & - & + & - & + \\
5 & $\mathrm{BCE}$ & - & + & + & + & + \\
6 & $\mathrm{ADE}$ & + & - & - & + & + \\
7 & $\mathrm{BDE}$ & - & + & - & + & + \\
8 & $\mathrm{ABCD}$ & + & + & + & + & + \\
\hline
\end{tabular}




\section{HASIL DAN PEMBAHASAN}

\section{Analisis Karakteristik Responden}

Analisis ini bertujuan untuk mengetahui keberagaman responden penumpang pesawat serta bisa mengetahui karakteristik perjalanan responden. Berdasarkan data yang diperoleh, karakteristik responden dan moda transportasi yang digunakan untuk menuju bandara dan/atau sebaliknya dapat dilihat pada Tabel 3. Dilihat dari hasil analisis data karakteristik responden sebanyak $54 \%$ responden menggunakan kendaraan pribadi sebagai akses untuk menuju bandara dan/atau sebaliknya dengan biaya sekitar Rp. 100.000 untuk satu kali perjalanan. Prosentase yang cukup besar dikarenakan mobilitas utama penduduk di Belitung adalah menggunakan kendaraan pribadi dan juga belum tersedianya sarana angkutan umum yang mampu melayani penumpang khususnya penumpang angkutan udara di Bandara H.A.S. Hanandjoedin. Pada Tabel 4 disampaikan gambaran berbagai macam faktor / alasan yang mempengaruhi penumpang angkutan udara memilih menggunakan transportasi tertentu sebagai akses menuju bandara dan/atau sebaliknya. Pada Tabel 4 diketahui bahwa responden memilih menggunakan kendaraan pribadi sebanyak $22 \%$ beranggapan bahwa lebih cepat dan sebanyak 26\% memilih menggunakan kendaraan sewa dengan alasan lebih cepat. Sebanyak $42 \%$ responden memilih menggunakan sepeda motor dikarenakan tidak ada atau belum tersedianya transportasi umum menuju bandara dan sebaliknya yang melayani daerah tersebut. Sehingga dengan menyediakan layanan transportasi angkutan pemadu moda diharapkan dapat memudahkan penumpang angkutan udara dengan kualitas pelayanan yang baik.

TABEL 3. Karakteristik responden

\begin{tabular}{|c|c|c|c|c|c|}
\hline Profil & Kategori & $\%$ & Profil & Kategori & $\%$ \\
\hline \multirow{2}{*}{ Jenis kelamin } & Pria & $64 \%$ & \multirow{6}{*}{$\begin{array}{c}\text { Moda yang } \\
\text { digunakan } \\
\text { menuju bandara }\end{array}$} & Mobil pribadi & $54 \%$ \\
\hline & Wanita & $36 \%$ & & Kendaraan sewa & $20 \%$ \\
\hline \multirow{5}{*}{$\begin{array}{c}\text { Maksud } \\
\text { perjalanan }\end{array}$} & Pendidikan & $16 \%$ & & Taksi & $3 \%$ \\
\hline & Pekerjaan & $34 \%$ & & Sepeda motor & $22 \%$ \\
\hline & Wisata & $11 \%$ & & Fasilitas hotel & $0 \%$ \\
\hline & Urusan keluarga & $32 \%$ & & Lainnya & $1 \%$ \\
\hline & Lainnya & $7 \%$ & \multirow{4}{*}{$\begin{array}{l}\text { Waktu menuju } \\
\text { bandara }\end{array}$} & $<30$ menit & $35 \%$ \\
\hline \multirow{6}{*}{$\begin{array}{l}\text { Frekuensi } \\
\text { perjalanan }\end{array}$} & 1 - 2 kali & $61 \%$ & & $\begin{array}{c}\text { antara } 30 \text { - } 60 \\
\text { menit }\end{array}$ & $47 \%$ \\
\hline & 3 - 4 kali & $32 \%$ & & $\begin{array}{c}\text { antara } 60 \text { - } 90 \\
\text { menit }\end{array}$ & $14 \%$ \\
\hline & 5 - 6 kali & $4 \%$ & & $>90$ menit & $4 \%$ \\
\hline & 7 - 8 kali & $3 \%$ & \multirow{7}{*}{$\begin{array}{c}\text { Biaya } 1 \mathrm{x} \\
\text { perjalanan }\end{array}$} & 20 ribu & $8 \%$ \\
\hline & 9 - 10 kali & $0 \%$ & & 50 ribu & $36 \%$ \\
\hline & $>10$ kali & $0 \%$ & & 100 ribu & $36 \%$ \\
\hline \multirow{4}{*}{$\begin{array}{l}\text { Penghasilan } \\
\text { (Rp) }\end{array}$} & $<1$ juta & $27 \%$ & & 150 ribu & 160 \\
\hline & $1-3$ juta & $37 \%$ & & 150 & 107 \\
\hline & $3-5$ juta & $31 \%$ & & \multirow{2}{*}{200 ribu } & \multirow{2}{*}{$4 \%$} \\
\hline & $>5$ juta & $5 \%$ & & & \\
\hline
\end{tabular}


TABEL 4. Alasan penggunaan moda transportasi tertentu menuju Bandara H.A.S. Hanandjoedin

\begin{tabular}{|c|c|c|c|c|c|c|c|c|}
\hline \multicolumn{9}{|c|}{ Transportasi yang digunakan menuju bandara } \\
\hline \multirow{2}{*}{ Alasan } & \multicolumn{2}{|c|}{ Mobil pribadi } & \multicolumn{2}{|c|}{ Kendaraan sewa } & \multicolumn{2}{|c|}{ Sepeda motor } & \multicolumn{2}{|c|}{ Taksi } \\
\hline & Frekuensi & $\%$ & Frekuensi & $\%$ & Frekuensi & $\%$ & Frekuensi & $\%$ \\
\hline Lebih cepat & 36 & $22 \%$ & 14 & $26 \%$ & 15 & $31 \%$ & 3 & $50 \%$ \\
\hline $\begin{array}{l}\text { Aman dan } \\
\text { nyaman }\end{array}$ & 31 & $19 \%$ & 12 & $22 \%$ & 2 & $4 \%$ & - & - \\
\hline $\begin{array}{l}\text { Mudah di } \\
\text { dapat }\end{array}$ & 10 & $6 \%$ & 5 & $9 \%$ & 5 & $10 \%$ & 1 & $17 \%$ \\
\hline $\begin{array}{l}\text { Lebih } \\
\text { murah }\end{array}$ & 1 & $1 \%$ & - & - & 5 & $10 \%$ & - & - \\
\hline $\begin{array}{l}\text { Lebih } \\
\text { mudah bawa } \\
\text { barang }\end{array}$ & 34 & $20 \%$ & 12 & $22 \%$ & 1 & $2 \%$ & 2 & $33 \%$ \\
\hline $\begin{array}{l}\text { Tidak perlu } \\
\text { berpindah- } \\
\text { pindah }\end{array}$ & 25 & $15 \%$ & - & - & - & - & - & - \\
\hline $\begin{array}{l}\text { Tidak ada } \\
\text { angkutan } \\
\text { umum yang } \\
\text { melayani } \\
\text { daerah }\end{array}$ & 30 & $18 \%$ & 11 & $20 \%$ & 20 & $42 \%$ & - & - \\
\hline Jumlah & 167 & $100 \%$ & 54 & $100 \%$ & 48 & $100 \%$ & 6 & $100 \%$ \\
\hline
\end{tabular}

\section{Analisis Faktor Pemilihan Atribut Pelayanan}

Untuk mengetahui tingkat preferensi calon penumpang terhadap layanan angkutan pemadu moda Bandara H.A.S. Hanandjoedin dilakukan dengan memberikan berbagai pilihan alternatif layanan pemadu moda. Dalam mengetahui tingkat preferensi calon penumpang angkutan pemadu moda bandara, digunakan beberapa atribut pelayanan (tarif, waktu perjalanan, jadwal keberangkatan, tipe perjalanan dan fasilitas) yang berpengaruh terhadap pemilihan moda dan masing-masing atribut terdiri atas dua level di mana atribut tersebut merupakan variable independent. Pada penelitian ini responden menyatakan pilihannya dengan menggunakan teknik rating, yang dibagi menjadi lima skala ordinal dan merupakan variable dependent. Atribut skenario yang digunakan dalam penelitian ini dapat dilihat pada Tabel 5 dan untuk hasil survei tingkat preferensi layanan angkutan pemadu moda terhadap 100 orang responden dapat dilihat pada Tabel 6.

Pada berbagai alternatif yang diberikan tarif yang ditentukan untuk satu kali perjalanan dengan dilakukan peningkatan terhadap layanan angkutan adalah sebesar Rp. 15.000 dan apabila tidak dilakukan peningkatan layanan tarifnya adalah sebesar Rp.10.000,-. Penetapan tarif ini didasarkan atas perhitungan biaya operasional kendaraan sesuai dengan rute rencana dan jenis kendaraan berdasarkan pada penelitian ini. Waktu perjalanan paling lama adalah 60 menit dan paling cepat adalah 45 menit. Untuk jadwal keberangkatan angkutan pemadu moda alternatif yang ditawarkan yaitu jadwal yang terkoordinasi sesuai dengan jadwal pesawat dan tidak terkoordinasi. Jadwal yang tidak terkoordinasi dengan jadwal pesawat akan direncanakan sesuai dengan hasil perhitungan yang didapat. Dari hasil yang telah didapatkan selanjutnya dilakukan analisis dengan bantuan software Limdep versi 7.0 (Limited Dependt Variable). Hasil analisis selengkapnya dapat dilihat pada Tabel 7. diperoleh persamaan sebagai berikut:

$y^{*}=0,257+0,734$ (travel cost $)+0,321$ (travel time $)+0,791$ (ticketing system) $+0,257$ (type of trip) $+0,300$ (facility)

untuk,

yi $=0$ (pasti tidak naik) : jika $y^{*}<0$

yi $=1$ (mungkin tidak naik) : jika $0<\mathrm{yi}^{*} \leq 0,67$

yi $=2$ (ragu-ragu) : jika $0,67<\mathrm{yi}^{*} \leq 1,25$

yi $=3$ (mungkin naik) : jika $1,25<\mathrm{yi}^{*} \leq 2,41$

yi $=4$ (pasti naik) : jika yi* $>2,41$

Dari hasil perhitungan untuk setiap skenario model diperoleh tingkat kemauan penumpang 
untuk menggunakan layanan angkutan pemadu moda seperti yang terlihat pada Tabel 8 . Berdasarkan hasil analisis yang diperoleh pada Tabel 8 dapat dilihat bahwa kecenderungan penumpang pesawat udara menginginkan tersedianya layanan angkutan pemadu moda sebagai akses untuk ke/dari bandara.

TABEL 5. Atribut skenario layanan angkutan pemadu moda Bandara H.A.S. Hanandjoedin

\begin{tabular}{|c|c|c|c|c|}
\hline Atribut & Alternatif 1 & Alternatif 2 & Alternatif 3 & Alternatif 4 \\
\hline Tarif & Rp 15.000,- & Rp 10.000,- & Rp 15.000,- & Rp 10.000,- \\
\hline $\begin{array}{l}\text { Waktu } \\
\text { perjalanan }\end{array}$ & 60 menit & 45 menit & 60 menit & 60 menit \\
\hline $\begin{array}{l}\text { Jadwal } \\
\text { keberangkatan }\end{array}$ & $\begin{array}{l}\text { Tidak } \\
\text { terkoordinasi }\end{array}$ & $\begin{array}{l}\text { Tidak } \\
\text { terkoordinasi }\end{array}$ & Terkoordinasi & Terkoordinasi \\
\hline Tipe perjalanan & $\begin{array}{l}\text { Tidak } \\
\text { langsung }\end{array}$ & Langsung & $\begin{array}{l}\text { Tidak } \\
\text { langsung }\end{array}$ & Tidak langsung \\
\hline Fasilitas & $\begin{array}{l}\text { Bersih, AC, } \\
\text { bagasi, tempat } \\
\text { duduk (Baik) }\end{array}$ & $\begin{array}{l}\text { Bersih, AC, } \\
\text { bagasi, tempat } \\
\text { duduk (Baik) }\end{array}$ & $\begin{array}{l}\text { Bersih, AC, } \\
\text { bagasi, tempat } \\
\text { duduk (Baik) }\end{array}$ & $\begin{array}{l}\text { Sangat bersih, } \\
\text { AC, bagasi, } \\
\text { tempat duduk, } \\
\text { tanggungan } \\
\text { asuransi (Sangat } \\
\text { baik) }\end{array}$ \\
\hline Atribut & Alternatif 5 & Alternatif 6 & Alternatif 7 & Alternatif 8 \\
\hline Tarif & Rp 15.000,- & Rp 10.000,- & Rp 15.000,- & Rp 10.000,- \\
\hline $\begin{array}{l}\text { Waktu } \\
\text { perjalanan }\end{array}$ & 45 menit & 60 menit & 45 menit & 45 menit \\
\hline $\begin{array}{l}\text { Jadwal } \\
\text { keberangkatan }\end{array}$ & Terkoordinasi & $\begin{array}{l}\text { Tidak } \\
\text { terkoordinasi }\end{array}$ & $\begin{array}{l}\text { Tidak } \\
\text { terkoordinasi }\end{array}$ & Terkoordinasi \\
\hline Tipe perjalanan & Langsung & Tidak langsung & Langsung & Langsung \\
\hline Fasilitas & $\begin{array}{l}\text { Sangat bersih, } \\
\text { AC, bagasi, } \\
\text { tempat duduk, } \\
\text { tanggungan } \\
\text { asuransi } \\
\text { (Sangat baik) }\end{array}$ & $\begin{array}{l}\text { Sangat bersih, } \\
\text { AC, bagasi, } \\
\text { tempat duduk, } \\
\text { tanggungan } \\
\text { asuransi } \\
\text { (Sangat baik) }\end{array}$ & $\begin{array}{l}\text { Sangat bersih, } \\
\text { AC, bagasi, } \\
\text { tempat duduk, } \\
\text { tanggungan } \\
\text { asuransi } \\
\text { (Sangat baik) }\end{array}$ & $\begin{array}{l}\text { Bersih, AC, } \\
\text { bagasi, tempat } \\
\text { duduk (Baik) }\end{array}$ \\
\hline
\end{tabular}

TABEL 6. Perilaku pemilihan angkutan pemadu moda Bandara H.A.S. Hanandjoedin

\begin{tabular}{lcccc}
\hline \multicolumn{1}{c}{ Perilaku } & $\begin{array}{c}\text { Alternatif 1 } \\
(\boldsymbol{\%})\end{array}$ & $\begin{array}{c}\text { Alternatif 2 } \\
(\boldsymbol{\%})\end{array}$ & $\begin{array}{c}\text { Alternatif 3 } \\
(\boldsymbol{\%})\end{array}$ & $\begin{array}{c}\text { Alternatif 4 } \\
(\boldsymbol{\%})\end{array}$ \\
\hline Pasti tidak naik (0) & 32 & 9 & 9 & 4 \\
Mungkin tidak naik (1) & 27 & 25 & 19 & 6 \\
Ragu-ragu (2) & 24 & 25 & 28 & 9 \\
Mungkin naik (3) & 13 & 33 & 31 & 45 \\
Pasti naik (4) & 4 & 8 & 13 & 36 \\
\hline \multicolumn{1}{c}{ Perilaku } & Alternatif 5 & Alternatif $\mathbf{6}$ & Alternatif 7 & Alternatif 8 \\
\hline Pasti tidak naik (0) & $(\boldsymbol{\%})$ & $(\boldsymbol{\%})$ & $(\boldsymbol{\%})$ & $(\boldsymbol{\%})$ \\
Mungkin tidak naik (1) & 7 & 6 & 7 & 3 \\
Ragu-ragu (2) & 13 & 13 & 17 & 3 \\
Mungkin naik (3) & 32 & 28 & 35 & 6 \\
Pasti naik (4) & 28 & 42 & 33 & 32 \\
\hline
\end{tabular}


TABEL 7. Hasil pemodelan

\begin{tabular}{|c|c|c|c|c|}
\hline Variabel & Koefisien & Standar Error & B/St/Er (Nilai t) & $\begin{array}{c}\mathbf{P}[\mid \mathrm{Z} />\mathbf{z}] \\
\text { (Signifikansi) }\end{array}$ \\
\hline \multicolumn{5}{|c|}{ "Index Function For Probability } \\
\hline Constant & 0.2576135937 & $0.49252300 \mathrm{E}-01$ & 4.633 & 0.0000 \\
\hline Travel cost & 0.7341817188 & $0.37120435 \mathrm{E}-01$ & 17.984 & 0.0000 \\
\hline Tavel time & 0.3210580497 & $0.38991204 \mathrm{E}-01$ & 9.677 & 0.0000 \\
\hline $\begin{array}{l}\text { Ticketing } \\
\text { system }\end{array}$ & 0.7916173782 & $0.36546069 \mathrm{E}-01$ & 18.240 & 0.0000 \\
\hline Type of trip & 0.2574739510 & $0.38868613 \mathrm{E}-01$ & 6.591 & 0.0000 \\
\hline Facility & 0.3002756812 & $0.39178481 \mathrm{E}-01$ & 7.676 & 0.0000 \\
\hline \multicolumn{5}{|c|}{ Threshold Prameters For Index } \\
\hline$\mu 1$ & 0.6729717547 & $0.29892747 \mathrm{E}-01$ & 23.676 & 0.0000 \\
\hline$\mu 2$ & 1.252679963 & $0.33285532 \mathrm{E}-01$ & 42.495 & 0.0000 \\
\hline$\mu 3$ & 2.415189788 & $0.41717730 \mathrm{E}-01$ & 60.620 & 0.0000 \\
\hline Chi-square & \multicolumn{4}{|c|}{782.1020} \\
\hline
\end{tabular}

TABEL 8. Hasil perhitungan skenario model

\begin{tabular}{cccccccc}
\hline \multirow{2}{*}{ Skenario } & \multicolumn{4}{c}{ Variabel bebas } & \multicolumn{3}{c}{ Kemauan penumpang } \\
\cline { 2 - 8 } & $\begin{array}{c}\text { Travel } \\
\text { cost }\end{array}$ & $\begin{array}{c}\text { Travel } \\
\text { time }\end{array}$ & $\begin{array}{c}\text { Ticketing } \\
\text { system }\end{array}$ & $\begin{array}{c}\text { Type of } \\
\text { trip }\end{array}$ & Facility & yi & Respon \\
\hline 1 & 0 & 0 & 0 & 0 & 0 & 0 & Pasti tidak naik \\
2 & 1 & 1 & 0 & 0 & 0 & 3 & Mungkin naik \\
3 & 0 & 0 & 1 & 1 & 0 & 3 & Mungkin naik \\
4 & 1 & 0 & 1 & 0 & 1 & 3 & Mungkin naik \\
5 & 0 & 1 & 1 & 0 & 1 & 2 & Ragu-ragu \\
6 & 1 & 0 & 0 & 1 & 1 & 3 & Mungkin naik \\
7 & 0 & 1 & 0 & 1 & 1 & 2 & Ragu-ragu \\
8 & 1 & 1 & 1 & 1 & 1 & 4 & Pasti naik \\
\hline
\end{tabular}

\section{Analisi Potensi Demand}

Analisis potensi demand merupakan analisis untuk mengetahui jumlah penumpang angkutan udara yang tertarik untuk menggunakan layanan angkutan pemadu moda di Bandara H.A.S. Hanandjoedin. Estimasi jumlah penumpang angkutan udara yang akan dilayani angkutan pemadu moda adalah sebanyak 575 orang.

\section{Perencanaan Sistem Operasional Angkutan Pemadu Moda}

\section{Penetapan rute}

Rute yang dianggap potensial untuk layanan angkutan pemadu moda Bandara H.A.S. Hanandjoedin dapat dilihat pada Gambar 1.

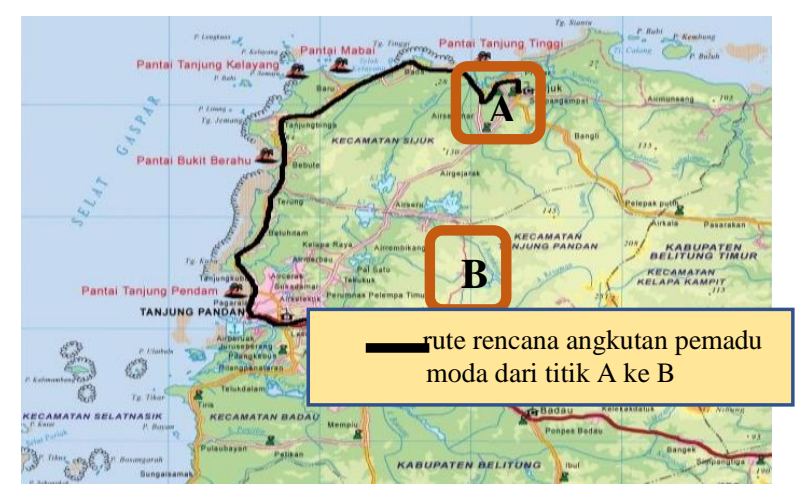

Berangkat : Tj.Tinggi - Tj. Kelayang - Tj.Pendam Jl. Sriwijaya - Jl. P.Diponegoro - Jl. Ahmad Yani Jl. Jend. Sudirman - Bandara H.A.S Hanandjoedin

Pulang : Bandara H.A.S. Hanandjoedin - Jl. Jend. Sudirman - Jl. Ahmad Yani - Jl. P. Diponegoro Jl. Sriwijaya - Tj. Pendam - Tj. Kelayang - Tg. Tinggi

GAMBAR 1. Penetapan rute rencana 


\section{Penentuan jenis kendaraan}

Penentuan jenis kendaraan dilakukan dengan berbagai faktor pertimbangan yang meliputi hasil survei responden. Berdasarkan data hasil kuesioner yang telah disebarkan kepada responden diperoleh hasil sebanyak 68\% responden memilih jenis kendaraan sedang dengan kapasitas 24 orang.

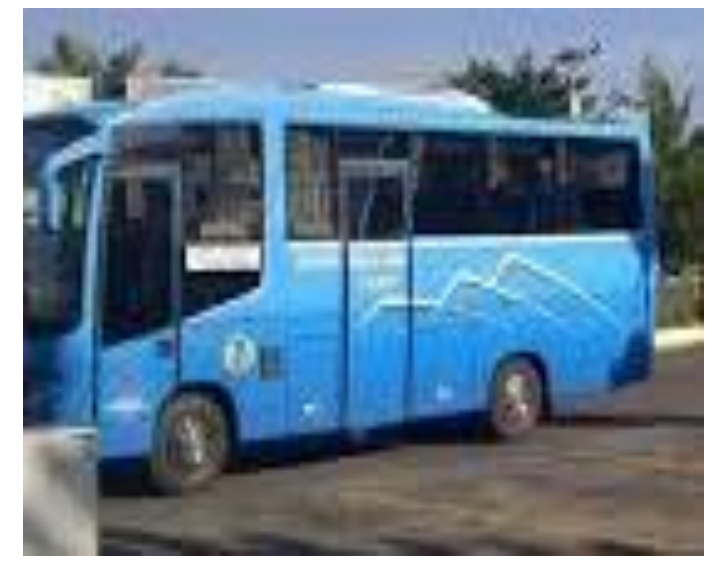

GAMBAR 2. Jenis kendaraan rencana

\section{Analisis sistem operasional angkutan pemadu moda}

Analisis sistem operasional angkutan pemadu moda Bandara H.A.S. Hanandjoedin terdiri dari beberapa hal sebagai berikut:

a. Faktor muat (load factor)

Nilai load factor diasumsikan 70\% (kondisi normal) calon penumpang akan menggunakan layanan angkutan pemadu moda

b. Headway

Headway yang diperoleh berdasarkan hasil perhitungan adalah 21 menit.

c. Waktu sirkulasi

Kecepatan rencana $60 \mathrm{~km} / \mathrm{jam}$, maka waktu tempu dari Terminal di Tj.Tinggi menuju Bandara H.A.S. Hanandjoedin adalah 45 menit. Deviasi waktu 5\% dari waktu perjalanan adalah 2,25 menit dan waktu henti $10 \%$ dari waktu perjalanan adalah 4,5 menit, maka waktu sirkulasi adalah 110 menit.

d. Jumlah kendaraan yang dibutuhkan per waktu sirkulasi

Jumlah kendaraan yang dibutuhkan untuk melayani suatu trayek dari sistem angkutan per waktu sirkulasinya, yaitu waktu yang dibutuhkan dari Terminal ke Bandara dan kembali ke Terminal adalah sebanyak 6 unit.

\section{Perencanaan tempat pemberhentian}

Dalam penelitian ini lokasi rencana halte diambil berdasarkan pertimbangan lokasi yang menjadi zona tarikan dan bangkitan dari perjalanan dengan tetap memperhatikan pedoman tata cara penempatan pemberhentian bus. Dari hasil identifikasi di lapangan ditetapkan beberapa titik halte yang melayani rute rencana angkutan pemadu moda dan juga terminal seperti yang terlihat pada Gambar 3 .

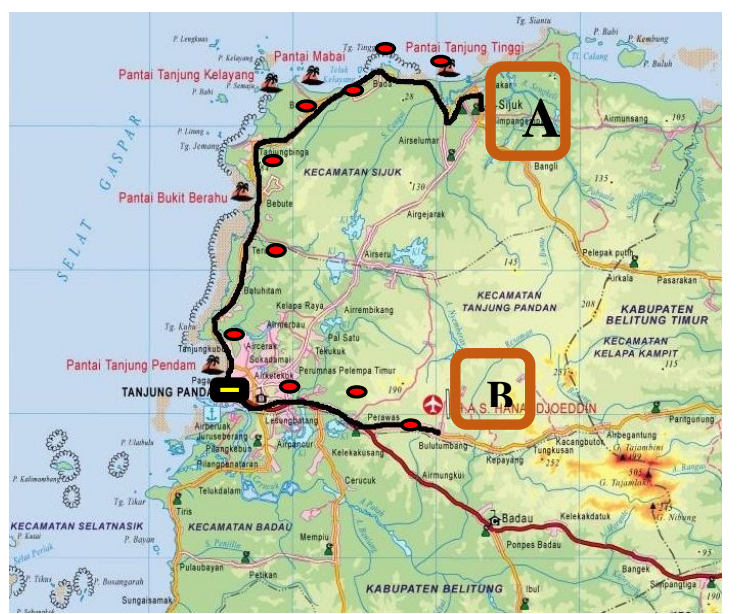

Keterangan:

Titik awal dan akhir $\bigcirc$ Halte
pemberhentian
Terminal kota/
Terminal Tanung Pandan

GAMBAR 3. Titik-titik halte pada rute rencana

\section{KESIMPULAN}

Berdasarkan hasil survey yang dilakukan terhadap penumpang pesawat udara di Bandara H.A.S. Hanandjoedin diperoleh sebanyak 56\% responden yang berminat untuk menggunakan layanan angkutan pemadu moda dengan adanya peningkatan dari aspek pelayanan, kecepatan, serta tarif angkutan pemadu moda. Berdasarkan jumlah responden yang berminat menggunakan layanan tersebut, diasumsikan sebagai potensi demand, yaitu sebesar $56 \%$ dari jumlah populasi sehingga diperoleh potensi demand sebanyak 575 penumpang/hari. Berdasarkan analisis yang telah dilakukan, dapat disimpulkan sistem operasional angkutan pemadu moda yang dapat diterapkan di Bandara H.A.S. 
Hanandjoedin adalah sebagai berikut: (a) angkutan pemadu moda yang digunakan adalah bus sedang dengan kapasitas 24 penumpang, (b) waktu pelayanan angkutan pemadu moda selama 12 jam/hari dengan jadwal keberangkatan disesuaikan dengan jadwal kedatangan dan keberangkatan pesawat. Angkutan pemadu moda mulai beroperasi pada pukul 05.00 dan pelayanan terakhir berangkat dari bandara mengikuti kedatangan pesawat yang terakhir, dan (c) operasional angkutan pemadu moda dengan kapasitas 24 orang, headway 21 menit, dan jumlah kendaraan yang dibutuhkan per waktu sirkulasi adalah sebanyak 6 unit.

\section{DAFTAR PUSTAKA}

Cochran, W. G. dan Cox, G. M. (1957). Experimental Design. New York: John Wiley \& Sons Ltd.

Joint Transport Research Centre (2008). The Role of Accesibility in Passengers, Choice of Airports. International Transport Forum. No. 2008-14.

Pearmin, D. dan Kroes, E. (1990). Stated Preference Techniques, A Guide To Practice. Richmond: Steer Davis \& Gleave Ltd.

Prayitno, E. (2008). Analisis Kemauan Penumpang Pesawat Udara untuk Menggunakan Bus Trans Jogja, Tesis, Program Studi Magister Sistem dan Teknik Transportasi. Yogyakarta: Universitas Gadjah Mada.

Prasetya, Y. dan Muthohar, I. (2012). Analisis Penerapan Integrasi Keretaa-Pesawat Di Bandara Adisutjipto Yogyakarta. Jurnal Forum Studi Transportasi Antar Perguruan Tinggi, Teknik Sipil dan Lingkungan.

Ortuzar, J.D. dan Willumsen, L.G. (1994). Modelling Transport-Second Edition. England: John Willey \& Sons Ltd.

Republik Indonesia, Undang-Undang No. 22 Tahun 2009 Tentang Lalu Lintas dan Angkutan Jalan.

Republik Indonesia, Peraturan Menteri Perhubungan No: KM 35 Tahun 2003, Tentang Penyelenggaraan Angkutan
Orang di Jalan dengan Kendaraan Umum.

Sugiyanto, G. dan Malkhamah, S. (2009). Model Pemilihan Moda Antar Mobil Pribadi dan Bis Trans Jogja Akibat Penerapan Biaya Kemacetan. Jurnal Transportasi, Vol. 9(2), 97-106.

Supriyanto, D. dan Widayanti, A. (2010). Kinerja Layanan Bis Kota di Kota Surabaya.

Tamin, O. Z. (2000). Perencanaan dan Permodelan Tranportasi. Bandung: Institut Teknologi Bandung.

PENULIS:

Sherly Devianty

Magister Sistem dan Teknik Transportasi, Fakultas Teknik, Universitas Gadjah Mada, Yogyakarta.

Email: devianty.21@gmail.com 